\title{
The Relationship between the Sports Manager Behavior and Locus of Control of Students Taking Sports Management Education
}

\author{
Abdurrahman Kepoglu \\ Usak University Faculty of Sport Sciences, Turkey. \\ Email:abdurrahman.kepoglu@usak.edu.tr Tel: +905553242568
}

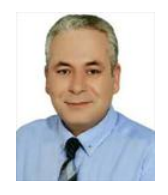

\begin{abstract}
The study aims to determine the degree to which sports managers show behaviors related to management processes and to what extent the focus of control of sports managers affects these behaviors, to increase the performance of sports managers. The universe of the research consists of $1^{\text {st }}, 2^{\text {nd }}, 3^{\text {rd }}$, and $4^{\text {th }}$-year students studying at the Department of Sports Management of Uşak University. The sample of the study, which was conducted with the non-probabilistic sampling method, in which 95\% confidence level and 5\% margin of error were used, consisted of 231 students, male $=155$, female $=76$. "Sports Manager Behavior Scale" and "Internal-External Locus of Control Scale" were used in the study. In general, it was determined that the students participating in the research have a very high level of sports manager behavior and internalExternal Locus of Control. 95.7\% of the students have internal control and $4.3 \%$ have an external locus of control.
\end{abstract}

Keywords: Sport manager behavior, Locus of control, Sport management education.

Citation | Abdurrahman Kepoglu (2021). The Relationship between the Sports Manager Behavior and Locus of Control of Students Taking Sports Management Education. Asian Journal of Education and Training, 7(1): 82-90.

History:

Received: 12 January 2021

Revised: 29 January 2021

Accepted: 22 February 2021

Published: 8 March 2021

Licensed: This work is licensed under a Creative Commons

Attribution 3.0 License $($ co)

Publisher: Asian Online Journal Publishing Group
Funding: This study received no specific financial support.

Competing Interests: The author declares that there are no conflicts of interests regarding the publication of this paper.

Transparency: The author confirms that the manuscript is an honest, accurate, and transparent account of the study was reported; that no vital features of the study have been omitted; and that any discrepancies from the study as planned have been explained.

Ethical: This study follows all ethical practices during writing.

\section{Contents}

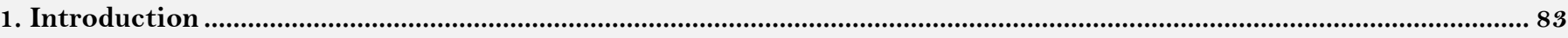

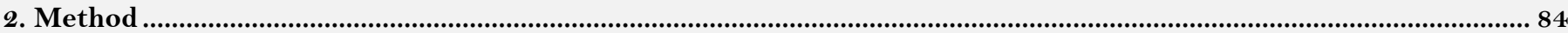

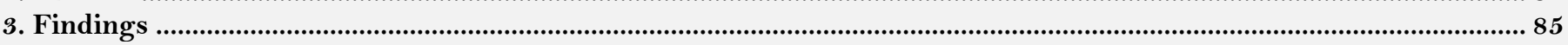

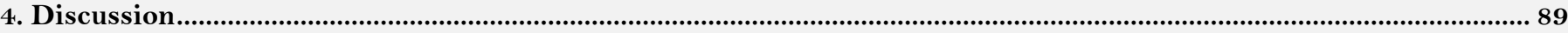

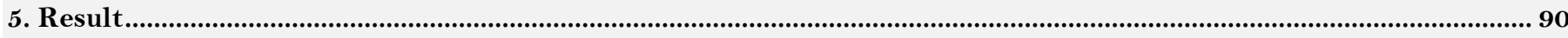

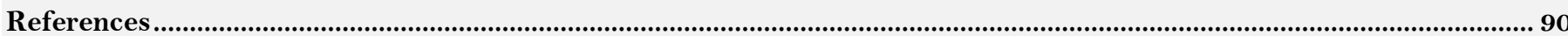




\section{Contribution of this paper to the literature}

This study contributes to existing literature by determining the degree to which sports managers show behaviors related to management processes and to what extent the focus of control of sports managers affects these behaviors, to increase the performance of sports managers.

\section{Introduction}

The main task of sports managers is to address the business side of sport so that athletes and coaches can focus on the competition. While you've probably attended many sporting events throughout your life, you might not have thought of the hard work that goes into keeping these games running smoothly. This is where the sports manager comes in. Sports managers are focused on monitoring the daily operations of sports facilities and all other playing surfaces. Sports managers work hard behind the scenes. Sports facility managers ensure that sports activities continue without interruption. In enterprises producing sports products; elements such as managers, athletes, trainers, facilities, equipment, and sports competition programs should be brought together by the objectives. The influence of managers' behavior, which has an important place in the lives of athletes, like all these factors, should not be overlooked. For this reason, the study aims to determine the degree to which sports managers show behaviors related to management processes and to what extent the focus of control of sports managers affects these behaviors, to increase the performance of sports managers.

Since the manager is the person who tries to reach the goals through others, he has to deal closely with the subject of behavior (Koçel, 1989). Although successful management in this respect is not alone, it largely relies on predicting and controlling human behavior (Celep, 1990). In short, it can be said that the manager has sufficient knowledge and skills about both his / her job and human behavior, both in terms of his / her success and its effect on the performance of athletes. Sports management, which is accepted as the application of the principles and rules of general management to the field of sports, is "a machine that makes sports with a hierarchical authoritarian regulation that maintains the distinction between the governor and the managed in the society as a manager and athlete" (Fişek, 1983). These developed concepts, mottos, methods, and principles have been adapted to fields such as industry, business, public, education, health, tourism, and sports and have been handled in different disciplines (Ekenci \& İmamoğlu, 2003). For every field (public administration, business administration, sports management, educational administration, etc.), specialization was made with in-depth scientific research.

Although management science is thought to have the same meaning for all social segments, the fact that the service, organization, and activities of the societies have different characteristics revealed that the characteristics of different fields should be taken into consideration. From this point on, although sports management is a sub-branch of management science and has many common features with management science, it should take into account the characteristics of its field in practice. Also, although management science is divided into different branches, management processes are valid for all branches (Yetim \& Günay, 1992). From this point of view, various stages of the management process such as planning, organization, execution, coordination, and control, are valid for various fields, and the principles and methods related to these are also valid for sports activities and sports organizations (Imamoğlu, 1992). Within the framework of this approach, sports management can be considered as the application of general management understanding to sports (Dolaşır, İmamoğlu, \& Sunay, 2002). Sports management is also seen as a professional job and it is accepted that it is no longer possible to manage sports amateurishly, only with enthusiasm or love (Imamoğlu, 1992). For this reason, besides the sports managers who will work in the field of sports love this job; they must have personal skills, experience, and professional knowledge (Yetim \& Günay, 1992). Sports management is defined as "the officers who take charge in the management and administration of sports services and activities in various ways and who contributed to the execution of these services and activities" (Demirci, 1986). In a broader sense, sports management is "the person who organizes the people working in the sports institution, gives orders, directs and organizes group work for the same purpose, takes all kinds of responsibilities and supervises the functioning to achieve the intended goals in the fields of physical education and sports.” (Yetim \& Şenel, 2001).

The managers must have certain qualifications to successfully fulfill the management functions related to the organization they are responsible for. These qualities are shaped by the skills revealed by the management scientist named Katz. These abilities are collected in three points: technical, human, and conceptual.

Technical Skill; It includes the expert knowledge of a specific field, the ability to analyze and to use analysis tools and techniques related to this field (Koçel, 1989). Technical skills are especially important for lower-level managers (Eren, 2003). It is observed that the weight of technical activities decreases as one moves from the hierarchical levels to the higher ranks (Bakır, 1994). For example, managing a sports facility requires different technical skills, but also includes complete technical knowledge about the sports branch managed (Imamoğlu, $1992)$.

Human Skill; As the level of the manager rises, instead of solving the problems with technical knowledge and providing technical support, the manager's planning, directing and coordination, etc. activities come to the fore (Mucuk, 1996) and hence human relations skills become important. In other words, the presence of a manager who attaches importance to human relations understands employees, and shows the ability to work in harmony with them is a source of happiness for employees in the organization (Balçık, 2002). Also, human skills play an important role in increasing the performance levels of employees. In particular, the human relations ability that sports managers should have is an important factor in maintaining harmony and resolving conflicts (Imamoğlu, 1992).

Conceptual Skill; It means that the manager sees the complete organization as a whole (Mucuk, 1996). But while seeing the whole, its parts should be well understood. To acquire this ability, they should be able to determine how each department affects other departments, what kind of change a change in one department will require in other departments, and individuals' relations with the environment, society, and industry (Dinçer \& Fidan, 1996).

In addition to these abilities of managers (Marşap, 2000; Mucuk, 1996) 
- A good manager must be honest and fair.

- He/She must be able to make his/her decisions on time.

- He/She must take responsibility.

- He/She must be initiative, dynamic and determined.

- He/She must be accepted in the environment with its external appearance, it should be tidy

- He/She must have integrative and coordinating skills.

- He/She must understand the emotions of the staff.

- He/She He must be able to perceive complex structures easily.

- $\mathrm{He} / \mathrm{She}$ must create a suitable atmosphere for the success of the organization.

- He/She must measure and evaluate the success of the organization.

Undoubtedly, it is not expected that every manager must have these qualities that are desired to be found in a good sports manager, but a sports manager who is trained in the framework of the aforementioned knowledge and has these characteristics can solve problems with scientific methods, not randomly, and thus make strategic, administrative executive decisions. It is possible to say that it can achieve more effective results (Imamoğlu, 1992).

Locus of Control perception is a personality parameter that considers whether rewards and punishments are a result of individuals' expectations or are realized by a force they believe against their will. In this case, individuals represent two different aspects of the two different behavioral styles they exhibit in the focus of control. One end of these two angles, which are indicated as opposites, defines internally controlled individuals who perceive rewards about their behavior, while the other end defines externally controlled individuals who connect the behaviors of the person to external factors (Yeşilyaprak, 1988). The belief that rewards and punishments occur as a result of the individual's behavior and that they are more influential in their emergence is called the "Internal Locus of Control". Individuals with the perception of Internal Locus of Control believe that the consistency between behaviors and results is a product of effort and success. This situation is perceived positively by the person. According to the locus of control (personality variable) scales, a relationship was found between the independence, work, and selfcontrolled attitudes of men who scored internally and academic efficacy (Nowicki \& Strickland, 1973). Pioneering authors in the field of locus of control, Rotter (1966); Phares (1976); Nowicki and Strickland (1973) stated that having internal control is effective in leading a successful and peaceful life.

If the individual has an internal locus of control, they take over responsibility for their behavior and change the expectations of their performances. While the individual with internal control has a more positive structure psychologically, this situation is not seen much in individuals with external control (Argun, 1995). The individual thinks that there is no inclination by himself in the formation of rewards and punishments and that these are applied by different forces other than himself. Therefore, the expectation that a person thinks that his or her efforts will not be effective, is called "External Locus of Control". When Kaplan, Reneau, and Whitecotton (2001) examine the relationship between personality variables and decision-making skills, they state that people with an external locus of control are more dependent on other people's opinions when making decisions compared to individuals with an internal locus of control. The internally controlled people act more independently. They act more resistant to the difficulties of the environment. Despite the obstacles they face, they display a constructive attitude. In an unsuccessful situation, they take responsibility without acting with the belief of external forces.

People who are prone to external control are more easily influenced. They have an accusatory and aggressive nature. They are incapable of realizing themselves (Ozen, 1991). While internally controlled individuals are individuals with high socioeconomic status, externally controlled individuals have low socio-economic status. External controllers state that external forces control the factors of events (Colangelo \& Davis, 1997). It has been found that individuals with external control feel more anger and see other people less as friends than individuals who have internal control.

\section{Method}

In this study, which aims to examine university students' sports manager behavior levels and control focus according to various variables, the relational screening method, one of the quantitative research designs, was used. This research design was chosen to analyze the differences between variables. It is a non-experimental design among quantitative research methods aiming to determine whether there is a relationship or difference between two or more independent variables (Karasar, 2016). The universe of the research consists of 1st, 2nd, 3rd, and 4thyear students studying at the Department of Sports Management of Usak University. The sample of the study, conducted with the non-probabilistic sampling method, in which $95 \%$ confidence level and $5 \%$ margin of error were used, consisted of 231 students, male $=155$, female $=76$. In this study, the "Sports Manager Behavior Scale" developed by Kepoglu and Bayansalduz (2021) was used. The 5-point Likert type scale consists of 5 subscales: Administrative Approach, self-efficacy approach, supportive approach, and hierarchical approach. One participant scores a minimum of 21 and a maximum of 105 points on the scale. The internal consistency reliability coefficient of the scale, which is scored as "Strongly Disagree (1) and Strongly Agree (5)), respectively; Sports Executive behavior scale $(\alpha=, 87)$ Administrative Approach $(\alpha=, 85)$ self-efficacy approach $(\alpha=, 82)$ supportive approach $(\alpha$ $=$, 63) hierarchical approach $(\alpha=, 57)$. In our study, Sports Manager behavior scale $(\alpha=.88)$ Administrative Approach $(\alpha=, 79)$ self-efficacy approach $(\alpha=, 77)$ supportive approach $(\alpha=, 65)$ was determined as a hierarchical approach $(\alpha=, 59)$. When these results are examined, it can be said that the reliability of the scale items regarding internal consistency among themselves is high. The other data collection tool used in the research was the "Internal-External Locus of Control Scale". Developed by Nowicki and Strickland (1973) the scale was adapted into Turkish by Ongen (2003). The Turkish form consists of 29 items and 5 subscales for family relationships, success, peer relationships, superstition, and fate. The scale is 4-point Likert type, and the subjects answer the scale items by choosing one of the options I strongly agree (1), strongly disagree (4). Internal-external locus of control scale ( $\alpha$ $=, 74)$ for family relationships $(\alpha=, 74)$ for success $(\alpha=, 59)$ for peer relations $(\alpha=, 61)$ for superstition $(\alpha=, 62)$ for fate foci were determined as $(\alpha=, 47)$. In our study, the internal consistency reliability coefficient of the internal- 
external control scale was determined as $(\alpha=, 70)$. According to this result, it can be said that the reliability of the scale is quite high.

\section{Findings}

The findings and solution suggestions about the determination of the sports manager qualifications levels of the students of the sports management department and the effects of the locus of control on the sports management characteristics acquired as a result of the training are given below.

\begin{tabular}{l|c|c|c}
\multicolumn{4}{c}{ Table-1. Descriptive statistics regarding students. } \\
\hline Variables & Groups & $\mathbf{f}$ & $\mathbf{\%}$ \\
\hline \multirow{2}{*}{ Gender } & Male & 155 & 67.1 \\
\cline { 2 - 4 } & Female & 76 & 32.9 \\
\hline \multirow{2}{*}{ Age } & $18-22$ & 198 & 85.7 \\
\cline { 2 - 4 } & $23-27$ & 22 & 9.5 \\
\cline { 2 - 4 } & 27 and over & 11 & 4.8 \\
\hline \multirow{3}{*}{ Grade } & $1^{\text {st }}$ Grade & 156 & 67.5 \\
\cline { 2 - 4 } & $2^{\text {nd }}$ Grade & 36 & 15.6 \\
\cline { 2 - 4 } & $3^{\text {rd }}$ Grade & 14 & 6.1 \\
\cline { 2 - 4 } & $4^{\text {th }}$ Grade & 25 & 10.8 \\
\hline \multirow{2}{*}{ Whether to do sports with a license } & Yes & 150 & 64.9 \\
\cline { 2 - 4 } & No & 81 & 35.1 \\
\hline
\end{tabular}

Note: $\mathrm{n}=231$.

As seen in Table $1,67.1 \%$ of the students participating in the study were male, $85.7 \%$ were students between the ages of $18-23,67.5 \%$ were first class and $64.9 \%$ were licensed sports. It consists of students who do.

Table-2. Normality analysis regarding scale and its sub-dimensions.

\begin{tabular}{|c|c|c|c|c|c|c|}
\hline Scales & Scales and Sub-Dimensions & $\bar{x} / \mathbf{s s}$ & median & variance & skewness & kurtois \\
\hline \multirow{5}{*}{$\begin{array}{l}\text { Sports } \\
\text { Manager } \\
\text { Behavior } \\
\text { Scale }\end{array}$} & Sports Manager Behavior General & $90.04 \pm 8.66$ & 90.00 & 75.05 & -0.461 & 0.623 \\
\hline & Administrative Approach & $30.72 \pm 3.23$ & 31.00 & 10.43 & -0.618 & 0.246 \\
\hline & Self-efficacy Approach & $30.53 \pm 3.18$ & 31.00 & 10.13 & -0.566 & 0.215 \\
\hline & Supportive Approach & $17.29 \pm 2.19$ & 17.00 & 4.83 & -0.860 & 1.003 \\
\hline & Hierarchical Approach & $11.48 \pm 2.18$ & 11.00 & 4.77 & -0.070 & -0.725 \\
\hline \multirow{6}{*}{$\begin{array}{l}\text { Internal- } \\
\text { External } \\
\text { Locus of } \\
\text { Control } \\
\text { Scale }\end{array}$} & $\begin{array}{l}\text { Internal-External Locus of Control } \\
\text { General }\end{array}$ & $85.26 \pm 11.09$ & 86.00 & 123.16 & -0.707 & 0.735 \\
\hline & Family Relations & $24.54 \pm 3.99$ & 25.00 & 15.93 & -0.465 & 0.511 \\
\hline & Success Relations & $16.16 \pm 5.33$ & 16.00 & 28.51 & 0.710 & 0.205 \\
\hline & Peer Relations & $22.94 \pm 5.74$ & 24.00 & 22.48 & -0.822 & 0.596 \\
\hline & Superstition Focus & $7.08 \pm 2.39$ & 8.00 & 5.75 & -0.535 & -0.747 \\
\hline & Fate Audit & $14.52 \pm 3.29$ & 15.00 & 10.88 & -0.613 & 0.375 \\
\hline
\end{tabular}

As seen in Table 2, normality analysis regarding the data has been made. The fact that the median and mean values are close to each other, the kurtosis and skewness values are between \pm 1.96 and the concentration of the data around the linear line in the $\mathrm{Q}-\mathrm{Q}$ pilot chart show that the data are suitable for normal distribution. For this reason, it has been decided to perform parametric tests in the analyzes to be used in analyzing the data.

Table-3. Descriptive statistics regarding the scale and sub-dimensions regarding participants.

\begin{tabular}{l|c|c|c|c}
\hline Scales & Minimum & Maximum & $\overline{\boldsymbol{x}}$ & Sd. \\
\hline Sports Manager Behavior General & 63 & 105 & 90.04 & 8.66 \\
\hline Internal-External Locus of Control General & 47 & 109 & 85.26 & 11.09 \\
\hline Note: $\bar{x}=$ mean; sd: standard deviation $n=231$.
\end{tabular}

As seen in Table 3, it can be said that, based on the averages, the students participating in the research generally have a very high level of sports manager behavior and internal-external control locus of control.

\begin{tabular}{l|c|c}
\multicolumn{2}{c}{ Table-4. Descriptive statistics regarding locus of control type of participants. } \\
\hline & Frequency & \% \\
\hline External Control & 10 & 4.3 \\
\hline Internal Control & 221 & 95.7 \\
\hline Total & 231 & 100 \\
\hline \multicolumn{2}{l}{ Note: As seen in Table 4, 95.7\% of the participating students have internal control and $4.3 \%$ have external locus of control. }
\end{tabular}

As seen in Table 5, a statistically significant difference was determined between the general scores of the sports manager behavior scale and the gender of the students at the $95 \%$ confidence level $\left(\mathrm{t}_{(229)}=-2,750 ; \mathrm{p}=, 006 ; \mathrm{p}<0,05\right)$. According to this result, it was determined that female students' sports manager behavior levels $(\bar{x}=92,25)$ were higher than male students $(\bar{x}=88,96)$. A statistically significant difference was found between the Administrative Approach subscale scores and the students' gender at $95 \%$ confidence level $\left(\mathrm{t}_{(229)}=-3,096 ; \mathrm{p}=, 002 ; \mathrm{p}<0,05\right)$. According to this result, it was determined that female students' Administrative Approach styles $(\bar{x}=31,57)$ were higher than male $(\bar{x}=30,31)$ students. A statistically significant difference was found between the self-efficacy approach subscale scores and the students' gender at the $95 \%$ confidence level $\left(\mathrm{t}_{(229)}=-3,007 ; \mathrm{p}=, 003 ; \mathrm{p}<0,05\right)$. According to this result, it was determined that female students' self-efficacy styles $(\bar{x}=31,42)$ were higher than male $(\bar{x}=30,10)$ students. A 
statistically significant difference was determined between the supportive approach subscale scores and the students' gender at the $95 \%$ confidence level $\left(\mathrm{t}_{(229)}=-2,554 ; \mathrm{p}=, 011 ; \mathrm{p}<0,05\right)$. According to this result, it was determined that the supportive approach styles of the female students $(\bar{x}=17,82)$ were higher than the male $(\bar{x}=17,04)$ students. However, no statistically significant difference was found between the hierarchical approach subscale scores and the gender of the students $(p=, 839 ; \mathrm{p}>0.05)$.

\begin{tabular}{|c|c|c|c|c|c|c|c|c|c|}
\hline \multirow{2}{*}{$\begin{array}{l}\text { Scales and Sub- } \\
\text { Dimensions }\end{array}$} & \multirow[b]{2}{*}{ Gender } & \multirow[b]{2}{*}{$\mathbf{n}$} & \multirow[b]{2}{*}{$\bar{x}$} & \multirow[b]{2}{*}{ Sd. } & \multicolumn{2}{|c|}{ Levene Test } & \multirow[b]{2}{*}{$\mathbf{t}$} & \multirow[b]{2}{*}{ df } & \multirow[b]{2}{*}{$p$} \\
\hline & & & & & $\mathbf{F}$ & $p$ & & & \\
\hline \multirow{2}{*}{$\begin{array}{l}\text { Sports Manager Behavior } \\
\text { General }\end{array}$} & Male & 155 & 88.96 & 9.15 & \multirow{2}{*}{2.57} & \multirow{2}{*}{0.110} & \multirow{2}{*}{-2.750} & \multirow{2}{*}{229} & \multirow{2}{*}{$0.006^{*}$} \\
\hline & Female & 76 & 92.25 & 7.13 & & & & & \\
\hline \multirow{2}{*}{ Administrative Approach } & Male & 155 & 30.31 & 3.43 & \multirow{2}{*}{6.594} & \multirow{2}{*}{0.011} & \multirow{2}{*}{-3.096} & \multirow{2}{*}{229} & \multirow{2}{*}{$0.002 *$} \\
\hline & Female & 76 & 31.57 & 2.59 & & & & & \\
\hline \multirow{2}{*}{ Self-efficacy Approach } & Male & 155 & 30.10 & 3.32 & \multirow{2}{*}{2.301} & \multirow{2}{*}{0.131} & \multirow{2}{*}{-3.007} & \multirow{2}{*}{229} & \multirow{2}{*}{$0.003 *$} \\
\hline & Female & 76 & 31.42 & 2.70 & & & & & \\
\hline \multirow{2}{*}{ Supportive Approach } & Male & 155 & 17.04 & 2.34 & \multirow{2}{*}{2.678} & \multirow{2}{*}{0.103} & \multirow{2}{*}{-2.554} & \multirow{2}{*}{229} & $0011 *$ \\
\hline & Female & 76 & 17.82 & 1.79 & & & & & 0.011 \\
\hline Hierarchical Anproach & Male & 155 & 11.51 & 2.15 & 006 & 0807 & 0903 & 909 & 0809 \\
\hline nerarchical Approacn & Female & 76 & 11.45 & 2.27 & 0.00 & 0.807 & 0.203 & 229 & 0.839 \\
\hline Internal-External Focus & Male & 155 & 86.17 & 10.90 & 0011 & 0916 & 1788 & 009 & 0075 \\
\hline of Control General & Female & 76 & 83.41 & 11.33 & 0.011 & 0.910 & 1.188 & 229 & 0.075 \\
\hline Family Relations & Male & 155 & 24.44 & 3.90 & & & & 299 & 0.579 \\
\hline r amily кеiations & Female & 76 & 24.75 & 4.20 & 1.799 & 0.181 & -0.556 & 229 & 0.579 \\
\hline Success Relations & Male & 155 & 16.46 & 5.47 & 0.389 & 0.537 & 1.203 & 299 & 0.930 \\
\hline & Female & 76 & 15.57 & 5.04 & 0.002 & 0.036 & 1.200 & 229 & 0.250 \\
\hline Peer Relations & Male & 155 & 23.07 & 4.67 & & 0795 & 0.589 & 909 & 0.561 \\
\hline reer nerations & Female & 76 & 22.68 & 4.90 & 0.124 & 0.125 & 0.582 & 229 & 0.561 \\
\hline Sunerstition Focus & Male & 155 & 7.58 & 2.15 & 4965 & 0040 & 4.389 & 909 & $0000 * *$ \\
\hline superstition Focus & Female & 76 & 6.08 & 2.58 & 4.265 & 0.040 & 4.383 & 229 & $0.000^{n}$ \\
\hline Fate Audit & Male & 155 & 14.62 & 3.29 & & & & & \\
\hline rate Aum & Female & 76 & 14.33 & 3.33 & 0.022 & 0.882 & 0.628 & 229 & 0.531 \\
\hline
\end{tabular}

Note: $* * \mathrm{p}<0.01 ;{ }^{*} \mathrm{p}<0.05 ; \bar{x}=$ mean; sd: standard deviation; df: degree of freedom.

Students' internal-external locus of control is based on the general scale $(\mathrm{p}=, 075 ; \mathrm{p}>0.05)$ and subscales; family relationships $(\mathrm{p}=, 579 ; \mathrm{p}>0.05)$, success relationships $(\mathrm{p}=$, 230; $\mathrm{p}>0.05)$, peer relationships $(\mathrm{p}=, 561 ; \mathrm{p}>$ $0.05)$, fate audit ( $\mathrm{p}=, 531 ; \mathrm{p}>0.05)$, there was no statistically significant difference between the averages of their scores and their gender. A statistically significant difference was found between the superstition focus subscale mean scores and the students' gender in the 95\% confidence scale $\left(\mathrm{t}_{(229)}=4.383 ; \mathrm{p}=.000 ; \mathrm{p}<0.05\right)$. According to the results of the analysis, it was determined that the superstition locus of control levels of men $(\bar{x}=7.58)$ were higher than that of women $(\bar{x}=6.08)$.

Table-6. Differential analyzes of participants' sports manager behavior and internal-external locus of control scales according to whether to do sports with a license.

\begin{tabular}{|c|c|c|c|c|c|c|c|c|c|}
\hline \multirow[b]{2}{*}{ Scale and Sub-Dimensions } & \multirow[b]{2}{*}{$\begin{array}{c}\text { Status of Being } \\
\text { a Licensed } \\
\text { Athlete }\end{array}$} & \multirow[b]{2}{*}{$\mathbf{n}$} & \multirow[b]{2}{*}{$\bar{x}$} & \multirow[b]{2}{*}{ Sd. } & \multicolumn{2}{|c|}{ Levene Test } & \multirow[b]{2}{*}{$\mathbf{t}$} & \multirow[b]{2}{*}{ sd } & \multirow[b]{2}{*}{ p } \\
\hline & & & & & $\mathbf{F}$ & p & & & \\
\hline \multirow{2}{*}{$\begin{array}{l}\text { Sports Manager Behavior } \\
\text { General }\end{array}$} & Yes & 150 & 90.50 & 8.49 & \multirow{2}{*}{0.075} & \multirow{2}{*}{0.785} & \multirow{2}{*}{1.091} & \multirow{2}{*}{229} & \multirow{2}{*}{0.276} \\
\hline & No & 81 & 89.20 & 8.96 & & & & & \\
\hline \multirow{2}{*}{ Administrative Approach } & Yes & 150 & 30.87 & 3.09 & \multirow{2}{*}{0.916} & \multirow{2}{*}{0.339} & \multirow{2}{*}{0.963} & \multirow{2}{*}{229} & \multirow{2}{*}{0.337} \\
\hline & No & 81 & 30.44 & 3.48 & & & & & \\
\hline \multirow{2}{*}{ Self-Efficacy Approach } & Yes & 150 & 30.73 & 3.06 & \multirow{2}{*}{0.412} & \multirow{2}{*}{0.522} & \multirow{2}{*}{1.279} & \multirow{2}{*}{229} & \multirow{2}{*}{0.202} \\
\hline & No & 81 & 30.17 & 3.39 & & & & & \\
\hline \multirow{2}{*}{ Supportive Approach } & Yes & 150 & 17.34 & 2.13 & \multirow{2}{*}{0.007} & \multirow{2}{*}{0.932} & \multirow{2}{*}{0.428} & \multirow{2}{*}{229} & 0660 \\
\hline & No & 81 & 17.21 & 2.34 & & & & & 0.669 \\
\hline Hiprorchical A proreach & Yes & 150 & 11.55 & 2.25 & 1500 & 0016 & 0607 & 900 & 0.545 \\
\hline Herarcnical Approacn & No & 81 & 11.37 & 2.08 & 1.539 & 0.216 & 0.607 & 229 & 0.545 \\
\hline Internal-External Focus of & Yes & 150 & 86.33 & 10.80 & 0809 & 0960 & $9 O O G$ & 900 & o 0 * \\
\hline Control General & No & 81 & 83.28 & 11.43 & 0.832 & 0.363 & 2.006 & 229 & $0.046^{\text {N }}$ \\
\hline Family Relations & Yes & 150 & 24.83 & 3.88 & 067 & 0.414 & 1489 & 929 & 0.139 \\
\hline & No & 81 & 24.01 & 4.16 & 0.08 & $0.41 \%$ & 1.483 & & 0.139 \\
\hline Success Relations & Yes & 150 & 16.19 & 5.35 & 0.488 & 0.485 & 0.069 & 929 & 0.945 \\
\hline & No & 81 & 16.14 & 5.36 & 0.488 & 0.480 & & & 0.940 \\
\hline Peer Relations & Yes & 150 & 23.59 & 4.48 & 1863 & 0174 & 0847 & 909 & $0005 *$ \\
\hline reer nerations & No & 81 & 21.75 & 5.00 & 1.863 & 0.174 & 2.847 & 229 & 0.005 \\
\hline Sunerstition Focus & Yes & 150 & 7.03 & 2.50 & o 917 & 0089 & -0.59 & 909 & 0607 \\
\hline superstition Focus & No & 81 & 7.20 & 2.21 & 2.917 & 0.089 & -0.52 & 229 & 0.607 \\
\hline Fate Audit & Yes & 150 & 14.71 & 3.15 & 1475 & 0906 & 1147 & 909 & 0959 \\
\hline & No & 81 & 14.19 & 3.55 & 1.465 & 0.226 & 1.147 & 229 & 0.253 \\
\hline
\end{tabular}

As seen in Table 6, sports manager behavior scale general score averages ( $p=, 276 ; p>0.05)$ and sub-scales Administrative Approach ( $\mathrm{p}=$, 337; $\mathrm{p}>0.05$ ), self-efficacy approach ( $\mathrm{p}=$. no significant difference was determined. 
A statistically significant difference was determined at a 95\% confidence level between the students' internalexternal locus of control general point averages and the variable of whether or not they are licensed athletes ( $t(229)$ $=2.006 ; \mathrm{p}<$. According to this result, it was determined that the students who do sports with a license have a higher internal-external locus of control $(\bar{x}=86.33)$ than the non-licensed students $(\bar{x}=83.28)$. A statistically significant difference was found between the peer relations subscale mean scores and the variable of doing sports with license or not at the $95 \%$ confidence level $(\mathrm{t}(229)=2.847 ; \mathrm{p}=.005 ; \mathrm{p}<0.05)$. Based on the averages, it was seen that the levels of peer relationships $(\bar{x}=23.59)$ of the students who are licensed sports are higher than the nonlicensed sports students $(\bar{x}=21.75)$. However, family relationships $(\mathrm{p}=, 139 ; \mathrm{p}>0.05)$, success relationships $(\mathrm{p}=$, 945; $>>0.05)$, superstition relationships $(\mathrm{p}=, 607 ; \mathrm{p}>0.05)$ and No significant difference was found between fate audit ( $\mathrm{p}=, 253 ; \mathrm{p}>0.05)$ and the variable of licensed sports or not.

Table-7. Sports manager behavior scale general score averages of the participants and analysis of the difference between the ages of the

\begin{tabular}{|c|c|c|c|c|c|c|c|c|}
\hline Scale and Sub-Dimensions & Age & $\mathbf{n}$ & $\overline{\bar{x}}$ & sd & df & $\mathbf{F}$ & p & LSD Difference \\
\hline \multirow{3}{*}{ Sports Manager Behavior General } & $18-22$ & 198 & 89.71 & 8.44 & \multirow{3}{*}{$\begin{array}{c}2 \\
228\end{array}$} & \multirow{3}{*}{3.416} & \multirow{3}{*}{$0.035^{*}$} & \multirow{3}{*}{$\begin{array}{l}1<3 \\
2<3\end{array}$} \\
\hline & $23-27$ & 22 & 89.73 & 9.69 & & & & \\
\hline & 27 and over & 11 & 96.64 & 8.70 & & & & \\
\hline \multirow{3}{*}{ Administrative Approach } & $18-22$ & 198 & 30.67 & 3.23 & \multirow{3}{*}{$\begin{array}{c}2 \\
228\end{array}$} & \multirow{3}{*}{1.79} & \multirow{3}{*}{0.169} & \\
\hline & $23-27$ & 22 & 30.32 & 3.40 & & & & \\
\hline & 27 and over & 11 & 32.45 & 2.50 & & & & \\
\hline \multirow{3}{*}{ Self-efficacy Approach } & $18-22$ & 198 & 30.48 & 3.16 & \multirow{3}{*}{$\begin{array}{c}2 \\
228\end{array}$} & \multirow{3}{*}{2.268} & \multirow{3}{*}{0.106} & \\
\hline & $23-27$ & 22 & 30.09 & 3.26 & & & & \\
\hline & 27 and over & 11 & 32.45 & 3.14 & & & & \\
\hline \multirow{3}{*}{ Supportive Approach } & $18-22$ & 198 & 17.23 & 2.22 & \multirow{3}{*}{$\begin{array}{c}2 \\
228\end{array}$} & \multirow{3}{*}{2.489} & \multirow{3}{*}{0.085} & \\
\hline & $23-27$ & 22 & 17.18 & 2.06 & & & & \\
\hline & 27 and over & 11 & 18.73 & 1.79 & & & & \\
\hline \multirow{3}{*}{ Hierarchical Approach } & $18-22$ & 198 & 11.33 & 2.17 & \multirow{3}{*}{$\begin{array}{c}2 \\
228\end{array}$} & \multirow{3}{*}{4.214} & \multirow{3}{*}{$0.016^{*}$} & \multirow{3}{*}{$1<3$} \\
\hline & $23-27$ & 22 & 12.14 & 1.98 & & & & \\
\hline & 27 and over & 11 & 13.00 & 2.19 & & & & \\
\hline \multirow{3}{*}{$\begin{array}{l}\text { Internal-External Focus of Control } \\
\text { General }\end{array}$} & $18-22$ & 198 & 85.67 & 10.86 & \multirow{3}{*}{$\begin{array}{c}2 \\
228\end{array}$} & \multirow{3}{*}{2.708} & \multirow{3}{*}{0.069} & \\
\hline & $23-27$ & 22 & 85.41 & 10.74 & & & & \\
\hline & 27 and over & 11 & 77.73 & 14.23 & & & & \\
\hline \multirow{3}{*}{ Family Relations } & $18-22$ & 198 & 24.53 & 4.11 & \multirow{3}{*}{$\begin{array}{c}2 \\
228\end{array}$} & & & \\
\hline & $23-27$ & 22 & 24.00 & 3.60 & & 0.764 & 0.467 & \\
\hline & 27 and over & 11 & 25.82 & 1.94 & & & & \\
\hline & $18-22$ & 198 & 16.20 & 5.13 & & & & \\
\hline Success Relations & 23-27 & 22 & 17.45 & 6.66 & $\stackrel{2}{2}$ & 2.615 & 0.075 & \\
\hline & 27 and over & 11 & 13.00 & 5.42 & & & & \\
\hline & $18-22$ & 198 & 23.19 & 4.64 & & & & \\
\hline Peer Relations & $23-27$ & 22 & 22.36 & 4.02 & $\stackrel{2}{2}$ & 3.007 & 0.051 & \\
\hline & 27 and over & 11 & 19.73 & 6.72 & & & & \\
\hline & $18-22$ & 198 & 7.15 & 2.38 & & & & \\
\hline Superstition Focus & $23-27$ & 22 & 7.27 & 2.45 & 2 & 2.438 & 0.090 & \\
\hline & 27 and over & 11 & 5.55 & 2.42 & & & & \\
\hline & $18-22$ & 198 & 14.60 & 3.33 & & & & \\
\hline Fate audit & $23-27$ & 22 & 14.32 & 3.31 & $\begin{array}{c}2 \\
908\end{array}$ & 0.486 & 0.616 & \\
\hline & 27 and over & 11 & 13.64 & 2.84 & & & & \\
\hline
\end{tabular}

Note: $* \mathrm{p}<0.05$

As seen in Table 7, a statistically significant difference was determined between the general score averages of the sports manager behavior scale and the ages of the students at the $95 \%$ confidence level $(\mathrm{F} 2-228)=3.416 ; \mathrm{p}=$ $.035 ; \mathrm{p}<0.05)$. When the source of the difference between the groups was examined, a significant difference was found between those aged between 18-22 and 27 and over, between 23-27 years old, and those aged 27 and over. According to this result, the sports manager behavior levels of the students aged 27 and over $(\bar{x}=96.64)$ are between 18-22 years old $(\bar{x}=89.71)$ and 23-27 years old $(\bar{x}=89.73)$ It was found to be higher than that. It can be said that as the students' age increases, the executive behavior style gained by the sports education they receive also improves. Administrative Approach ( $p=$, 169; $p>0.05)$, self-efficacy approach ( $\mathrm{p}=106 ; \mathrm{p}>0.05)$, supportive approach $(\mathrm{p}=, 085 ; \mathrm{p}>0.05)$. There was no statistically significant difference between their ages. However, a statistically significant difference was found between the ages of students at $95 \%$ confidence level with the hierarchical approach, one of the subscales $(\mathrm{F}(2-228)=4.214 ; \mathrm{p}=$, 016; $\mathrm{p}<0.05)$. When the source of the difference between the groups is examined, there is a significant difference between the students between the ages of 18-22 and those who are 27 and over. According to this result, it was determined that students aged 27 and over had higher hierarchical approach levels $(=13,00$ than students aged 18-22 $(=11,33)$. It can be said that as the age of the students increases, the hierarchical approach styles of the sports education they receive also increase.

The students' internal-external locus of control is based on the general scale $(p=$. family relationships $(p=$, 467; $p>0.05$ ), success relationships ( $p=$, 075; $p>0.05)$, peer relationships $(p=, 051 ; p>0.05)$, superstition focus ( $p$ No statistically significant difference was found between the mean scores of their scores and their age $(p=, 090 ; p>$ $0.05)$ and fate audit ( $\mathrm{p}=, 616 ; \mathrm{p}>0.05)$. 
Table-8. Analysis of the students' sports manager behavior and internal-external locus of control scales by class variable.

\begin{tabular}{|c|c|c|c|c|c|c|c|c|}
\hline Scale and Sub-Dimensions & Grade & $\mathbf{n}$ & Ort. & Sd. & Sd. & $\mathbf{F}$ & p & Discrepancy \\
\hline \multirow{4}{*}{$\begin{array}{l}\text { Sports Manager Behavior } \\
\text { General }\end{array}$} & $1^{\text {st }}$ Grade & 156 & 89.85 & 8.24 & \multirow{4}{*}{$\begin{array}{c}3 \\
227\end{array}$} & \multirow{4}{*}{2.588} & \multirow{4}{*}{0.054} & \\
\hline & $2^{\text {nd }}$ Grade & 36 & 89.19 & 10.21 & & & & \\
\hline & $3^{\text {rd }}$ Grade & 14 & 87.07 & 9.42 & & & & \\
\hline & $4^{\text {th }}$ Grade & 25 & 94.12 & 7.54 & & & & \\
\hline \multirow{4}{*}{ Administrative Approach } & $1^{\text {st }}$ Grade & 156 & 30.62 & 3.12 & \multirow{4}{*}{$\begin{array}{c}3 \\
227\end{array}$} & \multirow{4}{*}{4.652} & \multirow{4}{*}{$0.004^{*}$} & \multirow{4}{*}{$3<4$} \\
\hline & $2^{\text {nd }}$ Grade & 36 & 30.72 & 3.53 & & & & \\
\hline & $3^{\text {rd }}$ Grade & 14 & 28.71 & 3.75 & & & & \\
\hline & $4^{\text {th }}$ Grade & 25 & 32.52 & 2.37 & & & & \\
\hline \multirow{4}{*}{ Self-efficacy Approach } & $1^{\text {st }}$ Grade & 156 & 30.69 & 3.07 & \multirow{4}{*}{$\begin{array}{c}3 \\
227\end{array}$} & \multirow{4}{*}{3.068} & \multirow{4}{*}{$0.029 *$} & \multirow{4}{*}{$\begin{array}{l}2<4 \\
3<4\end{array}$} \\
\hline & $2^{\text {nd }}$ Grade & 36 & 29.72 & 3.42 & & & & \\
\hline & $3^{\text {rd }}$ Grade & 14 & 29.00 & 3.31 & & & & \\
\hline & $4^{\text {th }}$ Grade & 25 & 31.64 & 3.09 & & & & \\
\hline \multirow{4}{*}{ Supportive Approach } & $1^{\text {st }}$ Grade & 156 & 17.38 & 2.02 & \multirow{4}{*}{$\begin{array}{c}3 \\
227\end{array}$} & \multirow{4}{*}{0.515} & \multirow{4}{*}{0.672} & \\
\hline & $2^{\text {nd }}$ Grade & 36 & 16.89 & 2.83 & & & & \\
\hline & $3^{\text {rd }}$ Grade & 14 & 17.43 & 2.34 & & & & \\
\hline & $4^{\text {th }}$ Grade & 25 & 17.24 & 2.22 & & & & \\
\hline \multirow{4}{*}{ Hierarchical Approach } & $1^{\text {st }}$ Grade & 156 & 11.17 & 2.11 & \multirow{4}{*}{$\begin{array}{c}3 \\
227\end{array}$} & \multirow{4}{*}{4.513} & \multirow{4}{*}{$0.004^{*}$} & \\
\hline & $2^{\text {nd }}$ Grade & 36 & 11.86 & 2.22 & & & & $1<$ \\
\hline & $3^{\text {rd }}$ Grade & 14 & 11.93 & 1.82 & & & & $1<4$ \\
\hline & $4^{\text {th }}$ Grade & 25 & 12.72 & 2.32 & & & & \\
\hline & $1^{\text {st }}$ Grade & 156 & 85.64 & 9.90 & & & & \\
\hline Internal-External Focus of & $2^{\text {nd }}$ Grade & 36 & 85.17 & 13.55 & 3 & 0970 & $0 \times 4$ & \\
\hline Control General & $3^{\text {rd }}$ Grade & 14 & 84.21 & 12.26 & 227 & 0.278 & 0.841 & \\
\hline & $4^{\text {th }}$ Grade & 25 & 83.64 & 13.93 & & & & \\
\hline & $1^{\text {st }}$ Grade & 156 & 24.54 & 3.91 & & & & \\
\hline Fomily Polation & $2^{\text {nd }}$ Grade & 36 & 24.56 & 4.53 & 3 & 004 & $00 \Omega$ & \\
\hline Family Relations & $3^{\text {rd }}$ Grade & 14 & 24.21 & 3.38 & 227 & 0.041 & 0.989 & \\
\hline & $4^{\text {th }}$ Grade & 25 & 24.68 & 4.20 & & & & \\
\hline & $1^{\text {st }}$ Grade & 156 & 16.13 & 4.79 & & & & \\
\hline & $2^{\text {nd }}$ Grade & 36 & 16.86 & 6.28 & 3 & & & \\
\hline Success Relations & $3^{\text {rd }}$ Grade & 14 & 16.43 & 5.85 & 227 & 0.443 & 0.722 & \\
\hline & $4^{\text {th }}$ Grade & 25 & 15.28 & 6.91 & & & & \\
\hline & $1^{\text {st }}$ Grade & 156 & 23.09 & 4.62 & & & & \\
\hline Por Rolations & $2^{\text {nd }}$ Grade & 36 & 22.81 & 4.96 & 3 & & & \\
\hline Peer Relations & $3^{\text {rd }}$ Grade & 14 & 22.36 & 5.23 & 227 & 0.183 & 0.908 & \\
\hline & $4^{\text {th }}$ Grade & 25 & 22.56 & 5.15 & & & & \\
\hline & $1^{\text {st }}$ Grade & 156 & 7.31 & 2.20 & & & & \\
\hline Sunonctition Fouи & $2^{\text {nd }}$ Grade & 36 & 6.53 & 2.77 & 3 & $a c c 0$ & o 0 米 & \\
\hline Superstition Focus & $3^{\text {rd }}$ Grade & 14 & 7.64 & 2.44 & 227 & 2.669 & $0.048 *$ & $1>4$ \\
\hline & $4^{\text {th }}$ Grade & 25 & 6.16 & 2.76 & & & & \\
\hline & $1^{\text {st }}$ Grade & 156 & 14.56 & 3.21 & & & & \\
\hline Fate audit & $2^{\text {nd }}$ Grade & 36 & 14.42 & 3.50 & 3 & 0.550 & & \\
\hline Fate audit & $3^{\text {rd }}$ Grade & 14 & 13.57 & 2.85 & 227 & 0.552 & 0.648 & \\
\hline & $4^{\text {th }}$ Grade & 25 & 14.96 & 3.86 & & & & \\
\hline
\end{tabular}

As seen in Table 8 , with the general score averages of the sports manager behavior scale $(p=.054 ; p>0.05)$ and the supportive approach from the subscales $(\mathrm{p}=, 672 ; \mathrm{p}>0.05)$, the students' level of education There was no statistically significant difference.

However, a statistically significant difference was determined at a $95 \%$ confidence level between the Administrative Approach and the class levels students studied $(\mathrm{F}(2-227)=4.652 ; \mathrm{p}=$, 029; $\mathrm{p}<0.05)$. When the source of the difference between the groups is examined, there is a significant difference between the 3rd grade and the 4th grade. Accordingly, it has been determined that the students studying in the 4th grade $(\bar{x}=32.52)$ are higher than those studying in the 3rd grade $(\bar{x}=28.71)$. According to this result, it can be said that as the grade levels of students studying in the department of management increase, their managerial behavior styles also improve.

In addition to this, a statistically significant difference was determined at the $95 \%$ confidence level between the self-efficacy approach and the level of students' education $(\mathrm{F}(2-227)=3.068 ; \mathrm{p}=$, 008; $\mathrm{p}<0.05)$. When the source of the difference between the groups is examined, there is a significant difference between the 2nd grade and 4th grade, and between 3rd and 4th grade. Accordingly, it was found that the Administrative Approach levels of the students studying in the 4th grade $(\bar{x}=31.64)$ were higher than those of the 2 nd grade $(\bar{x}=29.72)$ and the 3rd grade $(\bar{x}=29.00)$ has been.

With the hierarchical approach, a statistically significant difference was determined at a $95 \%$ confidence level between the grade levels the students studied $(\mathrm{F}(2-227)=4.513 ; \mathrm{p}=, 048 ; \mathrm{p}<0.05)$. When the source of the difference between the groups is examined, there is a significant difference between the 1st grade and the 4th grade. Accordingly, it has been determined that the students studying in the 4th grade $(\bar{x}=12.72)$ are higher than those studying in the 3rd grade $(\bar{x}=11.93)$.

Students' internal-external locus of control is based on the general scale $(p=, 841 ; p>0.05)$ and subscales; family relationships $(\mathrm{p}=, 989 ; \mathrm{p}>0.05)$, success relationships $(\mathrm{p}=, 722 ; \mathrm{p}>0.05)$, peer relationships $(\mathrm{p}=, 908 ; \mathrm{p}>$ $0.05)$, and fate audit ( $\mathrm{p}=, 648 ; \mathrm{p}>0.05)$, there was no statistically significant difference between the averages of their scores and their grade levels. However, a statistically significant difference was found at a $95 \%$ confidence level between the superstition focus and the grade levels the students studied $(\mathrm{F}(2-227)=2.669 ; \mathrm{p}=$, 004; $\mathrm{p}$ 
$<0.05)$. When the source of the difference between the groups is examined, there is a significant difference between the 1 st grade and the 4th grade. Accordingly, it was determined that the students studying in the 1 st grade $(\bar{x}=$ $7.31)$ are higher than the students studying in the 4th grade $(\bar{x}=6.16)$. According to this result, it can be said that with the effect of the management education students received, there was a decrease in superstition focus and scientific approaches were adopted more.

\begin{tabular}{l|c|c}
\multicolumn{2}{l|}{ Table-9. The relationship analysis between students' sports manager behavior levels and internal-external locus of control. } \\
\hline & & Sports Manager Behavior Level \\
\hline Locus of control Level & Pearson Correlation & -0.126 \\
\hline & $\mathrm{p}$ & 0.056 \\
\hline & $\mathrm{N}$ & 231 \\
\hline
\end{tabular}

Note: $\mathrm{p}<0.05$

There is no relationship between students' sports manager behavior levels and internal-External Locus of Control ( $p>0.05)$. Therefore, control focus has no effect on the behavior levels of students' sports managers.

\section{Discussion}

In our study, sports manager behavior levels and internal-external locus of control levels of the sports management department students were determined. The relationship and effect of the type of locus of control that students have with their sports manager behavior levels were determined. From this point; As seen in Table 1, $67.1 \%$ of the students participating in the study were males, $85.7 \%$ were students between the ages of $18-23,67.5 \%$ were first class and $64.9 \%$ were licensed sports. It consists of students who do.

As can be seen in Table 3, it can be said that the students participating in the research generally have a very high level of sports manager behavior and internal-External Locus of Control based on the averages.

As seen in Table 4, 95.7\% of the participating students have internal audits and $4.3 \%$ have an external locus of control.

As seen in Table 5, a statistically significant difference was determined between the general scores of the sports manager behavior scale and the gender of the students. According to this result, it was determined that the sports manager behavior levels of female students were higher than the male students. A statistically significant difference was found between the Administrative Approach subscale scores and the students' gender at the 95\% confidence level. According to this result, it was determined that female students' Administrative Approach styles were higher than students. A statistically significant difference was determined between the self-efficacy approach subscale scores and the gender of the students. According to this result, it was determined that the self-efficacy styles of female students were higher than male students. A statistically significant difference was determined between the supportive approach subscale scores and the gender of the students. According to this result, it was determined that the supportive approach styles of female students were higher than male students. However, no statistically significant difference was found between the hierarchical approach subscale scores and the students' gender. Students' internal-external locus of control is based on the overall and subscales; No statistically significant difference was found between family relationships, success relationships, peer relationships, the averages of their scores from fate, and their gender. A statistically significant difference was determined between the superstition focus subscale to mean scores and the gender of the students. According to the results of the analysis, it was determined that male students had higher levels of superstition locus of control than female students.

As seen in Table 6, a statistically significant difference was not determined between the general score averages of the sports manager behavior scale and the sub-scales Administrative Approach, self-efficacy approach, supportive approach, and the hierarchical approach, and the variable of whether or not students do sports with a license. A statistically significant difference was determined between the students' internal-external locus of control general point averages and the variable of whether or not they are licensed athletes. According to this result, it was determined that the students who do sports with a license have a higher internal-external locus of control than the non-licensed students. A statistically significant difference was determined between the peer relations subscale mean scores and the variable of exercising with license or not. Based on the averages, it has been observed that the peer relationship level of the students who are licensed sports is higher than the students who are not licensed, sportsmen. However, no significant difference was found between family relationships, success relationships, superstition relationships, and fate audit, and licensed exercising or not.

As seen in Table 7, a statistically significant difference was not determined between the general score averages of the sports manager behavior scale and the supportive approach from the sub-scales, and the grade levels of the students. However, a statistically significant difference was determined between the Administrative Approach, which is one of the subscales, and the level of the students' education. When the source of the difference between the groups is examined, there is a significant difference between the 3rd grade and the 4th grade. Accordingly, it was determined that the students studying in the 4th grade are higher than the students in the 3rd grade. According to this result, it can be said that as the grade levels of students studying in the department of management increase, their managerial behavior styles also improve. In addition to this, a statistically significant difference was determined between the self-efficacy approach and the grade levels of the students. When the source of the difference between groups is examined, there is a significant difference between the 2 nd grade and the 4th grade, and between the 3rd grade and the 4th grade. Accordingly, it was determined that the Administrative Approach levels of 4th-grade students were higher than those studying in the 2 nd and 3 rd grade $\left(\mathrm{x}^{-}=29,00\right)$. With the hierarchical approach, a statistically significant difference was determined between the grade levels the students studied. When the source of the difference between the groups is examined, there is a significant difference between 1 st grade and 4th grade. Accordingly, it has been determined that 4th-grade students are higher than 3rd-grade students.

Students' internal-external locus of control is based on the overall and subscales; There was no statistically significant difference between family relationships, achievement relationships, peer relationships, and the average scores of their fateful control and their grade level. However, a statistically significant difference was found 
between the superstition focus of the subscales and the level of the students' education. When the source of the difference between the groups is examined, there is a significant difference between the 1st grade and the 4th grade. Accordingly, it has been determined that the students studying in the 1st grade are higher than those studying in the 4th grade. According to this result, it can be said that with the effect of the management education students received, there was a decrease in superstition focus and scientific approaches were adopted more.

As can be seen in Table 8, there is no relationship between students' sports manager behavior levels and internal-External Locus of Controls. Therefore, control focus does not affect students' sports manager behavior levels.

\section{Result}

In general, it was determined that the students participating in the study have a very high level of sports manager behavior and internal-External Locus of Control. $95.7 \%$ of the students have internal audits and $4.3 \%$ have an external locus of control. There is no relationship between students' sports manager behavior levels and internal-external control centers. Therefore, control focus does not affect students' sports manager behavior levels. Despite this situation, an important factor to be taken into account is that students have not yet started their profession. However, as the duration of education increases, sports manager behavior levels also increase. When they start sports management in sports businesses; as they are mainly focused on internal control and according to the behavioral patterns derived from personality traits; they will act more independently. They will act more resistant to the difficulties coming from the inner and outer environment of the sports business. Despite the obstacles they face, they will be able to take a constructive attitude. In an unsuccessful situation, they will be able to assume responsibility without acting with the belief of external forces. When making decisions like those with an external locus of control; they will not be more dependent on other people's opinions. They will not be affected more easily. They will not be accusing or aggressive and will not be incapable of self-understanding. With these features they carry, they will be able to exhibit high-level sports manager behavior in the sports businesses they will work. Another result that should be taken into consideration is that although female sports management students have higher sports manager behavior level, in practice, they have quite a few sports manager positions in sports businesses compared to men. One of the possible reasons for this situation is that female sports management students are more focused on external control.

\section{References}

Argun, Y. (1995). The effects of parents 'child rearing attitudes on secondary school students' locus of control. Unpublished Master's Thesis, Dokuz Eylül University Institute of Social Sciences, İzmir.

Bakır, M. (1994). The scope of sports management based on modern management approach. Gazi University Journal of Physical Education and Sports Sciences, 4(2), 73-80.

Balçık, B. (2002). Business management. Ankara: Nobel Publishing.

Celep, C. (1990). The role of managerial behaviors in employees' job success and the case of SEE, Sakarya University institute of social sciences, department of educational management, inspection, planning and economics. PhD Thesis, Sakarya.

Colangelo, N., \& Davis, G. A. (1997). Handbook of gifted education (2nd ed.). Boston: Allyn \& Bacon.

Demirci, N. (1986). Management-organization and organizations in Sport: TR Ministry of National Education, Youth and Sports.

Dinçer, Ö., \& Fidan, Y. (1996). Business management. Istanbul: Beta Publishing.

Dolaşır, S., İmamoğlu, F., \& Sunay, H. (2002). Human resources management approach in Turkish sports management. Gazi University Journal of Physical Education and Sport Sciences, 7(1), 40-45.

Ekenci, G., \& İmamoğlu, F. (2003). Sports management. Ankara: Nobel Publishing.

Eren, E. (2003). Management and organization. İstanbul: Beta Publishing.

Fişek, K. (1983). Sports management. Ankara: Beta Publishing.

Imamoğlu, F. (1992). The meaning and importance of sports management in functional perspective. Gazi University Journal of Education Faculty, 8(1), 21-34.

Kaplan, S. E., Reneau, J. H., \& Whitecotton, S. (2001). The effects of predictive ability information, locus of control, and decision maker involvement on decision aid reliance. Journal of Behavioral Decision Making, 14(1), 35-50.Available at: https://doi.org/10.1002/1099-0771(200101)14:1\%3C35::aid-bdm364\%3E3.0.co;2-d.

Karasar, N. (2016). Scientific research method. Ankara: Nobel Publishing.

Kepoglu, A., \& Bayansalduz, M. (2021). Validity and reliability study of "Sports Manager Behavior Scale" in sports manager education. International Journal of Applied Exercise Physiology, 10(2), 52-63.

Koçel, T. (1989). Business management. Istanbul: Faculty of Business Publications.

Marşap, A. (2000). Administrative system. Ankara: Gazi Bookstore.

Mucuk, İ. (1996). Modern business. Istanbul: Turkmen Kitap.

Nowicki, S., \& Strickland, B. A. (1973). Locus of control scale for children. 1. Consult Clinical Psychology, 4O(1), 148-154.

Ongen, D. (2003). Validity and reliability study of focal point scale. Journal of Education Management in Theory and Practice, 35(35), 436-447.

Ozen, N. (1991). The relationship between focus of control and self-acceptance. Journal of Psychological Counseling and Guidance, 1(2), 20-28.

Phares, E. J. (1976). Locus of control in personality: Kansas State University General Learning Press.

Rotter, J. (1966). Generalized expectancies for internal versus external control of reinforcement. Psychological Monographs, 80, 1-28.Available at: https://doi.org/10.1037/hoo92976.

Yeşilyaprak, B. (1988). Factors affecting the internal or external control of high school students. Hacettepe University. Unpublished Doctoral Thesis. Ankara.

Yetim, A., \& Günay, M. (1992). Management processes and sports management. Gazi University Journal of Physical Education and Sport Sciences, $8(1), 1-8$.

Yetim, A., \& Şenel, Ö. (2001). Sports manager in Turkey view of growing activity. Journal of National Education, 1(5), 1-8. 